O. V. Pylypenko, N. A. Konovalov, V. I. Kovalenko, D.V. Semenchuk

\title{
Compact silencers with discrete baffle elements for new-generation light small arms
}

\author{
Institute of Technical M echanics \\ of the National Academy of Sciences of $U$ kraine and the State Space Agency of U kraine \\ 15 Leshko-Popel St., D nipro 49005, U kraine; e-mail: office.itm@ nas.gov.иa
}

\begin{abstract}
This paper presents the results of the development of silencers, whose design features discrete baffle elements. The advisability of silencers of this type is confirmed by their operational reliability and shot sound suppression efficiency in their actual service as part of light small arms of different types.

To design advanced silencers, technical requirements for their design were developed. The paper describes the possibility of using discrete elements (cones, hemispheres, flat baffles, etc.) as the key component of a powder gas spreader. Differently shaped elements are used as additional elements that form a powder gas flow inside a silencer: for example, cylindrical elements, including perforated ones to provide a powder gas flow between the expansion chambers. One way to increase silencer efficiency is an additional expansion chamber that embraces the external part of the barrel and is gas-dynamically connected to a traditional muzzle silencer.

In deciding on an optimum design for compact silencers, the following was redetermined: the number of expansion chambers and the dimensions thereof, the powder gas energy converter design, the baffle type, the presence of a gas flow between the chambers near the inner surface of the silencer body, and, if so, the gas flow rate.

The silencer design was optimized based on simulating the processes inside the silencer using the authors' efficiency calculation procedure for silencers with different internal components.

Comparison tests of the silencers developed and foreign silencers confirmed a high efficiency of the former.

The silencers with discrete baffles for light small arms developed at the Institute of Technical Mechanics of the National Academy of Ukraine and the State Space Agency of Ukraine compare well in performance with their best foreign counterparts. The designs of some of them are covered by Ukrainian patents.
\end{abstract}

Keywords silencer, cone, hemisphere, expansion chamber, computational procedure, shot sound suppression efficiency.

1. Konovalov N. A., Pylypenko O. V., Skorik A. D., Kvasha Yu. A., Kovalenko V. I. Silent Hand Firearms. Submachine Gun Silencers. Design and Experimental Development. Dnipropetrovsk: Institute of Technical Mechanics of the National Academy of Sciences of Ukraine and the National Space Agency of Ukraine, 2008. 303 pp. (in Russian).

2. Konovalov M. A., Pylypenko O. V., Kvasha Yu. O., Sichevyi O. V., Skorik O. D., Strelnikov H. O. Silent Automatic Firearms: Manual. Dnipropetrovsk: ART-PRESS, 2011. 340 pp. (in Ukrainian).

3. Neugodov A. S., Sabelnikov V. M. Small Arms Acoustics. Moscow: Central Research institute of Information, 1979. 150 pp. (in Russian).

4. On devices for silent and flareless shooting. URL: http://www.gutierrez.3dn.ru/blog/silensers/2011-06-11-6 (last accessed on May 15, 2021). (in Russian).

5. Juha Hartikka. Silencer that is by no means silent. Master-Ruzhye. 2010. No. 159. Pp. 52-57. URL: http://master-gun.com/pdfs/159.pdf (last accessed on May 15, 2021). (in Russian).

6. Konovalov N. A., Pylypenko O. V., Skorik A. D., Kovalenko V. I., Bilenko A. I. Development and full-scale tests of unified sound suppressors for small arms. Teh. Meh. 2014. No. 1. Pp. 3-10. (in Russian).

7. Acoustic fire detection systems. SOVA hears a bullet. (Acoustic systems for small arms fire detection developed by the All-Russian Scientific Research Institute of Experimental Physics). 
URL: http://alternathistory.com/akusticheskie-sistemy-obnaruzheniya-ognya-sova-slyshit-pulyu/ (last accessed on May 15, 2021). (in Russian).

8. Konovalov N. A., Pylypenko O. V., Skorik A. D., Kovalenko V. I., Zagreba A. I., Pikhotenko S. V., Yakovlev S. V. Small-arms titanium alloy silencer design and manufacturing technique development. Teh. Meh. 2013. No. 1. Pp. 78-95. (in Russian).

9. Konovalov N. A., Pylypenko O. V., Polyakov G. A., Skorik A. D., Gunko A. D., Yakimenko M. A., Kovalenko V. I. Silencer for special unit submachine guns. Teh. Meh. 2012. No. 2. Pp. 50-76. (in Russian).

10. Heckler \& Koch MP5. URL: https://ru.wikipedia.org/wiki/HK_MP5 (last accessed on April 18, 2018). (in Russian).

11. Heckler \& Koch MP5 and its clones. URL: https://zbroya.info/ru/blog/ 12282_hecklerkoch-mp5-i-ego-klony/ (last accessed on April 18, 2018). (in Russian).

12. Pylypenko O. V., Konovalov N. A., Kovalenko V. I., Semenchuk D. V. Silencers with spherical baffles for submachine guns, Teh. Meh. 2018. No. 2. Pp. 5-16. (in Russian). https://doi.org/10.15407/itm2018.02.005

13. Murakhovsky V. I., Fedoseev S. L. Infantry Arms. Moscow: Arsenal-Press, 1997. 400 pp. (in Russian).

14. Murakhovsky V. I., Slutsky E. A. Special-Purpose Arms: Handbook. Moscow: Elakos, 1995. 212 pp. (in Russian).

15. Small-arms shot sound suppressor and director: Patent 28410 Ukraine: IPC (2006) F41A 17/00, F41A 21/30 (2006.01). Konovalov M. A., Ostapov A. I., Pylypenko O. V., Polyakov G. A., Skorik O. D., Tynyna S. V., Chaplyts O. D.; applicant and patentee Institute of Technical Mechanics of the National Academy of Sciences of Ukraine and the National Space Agency of Ukraine. No. u2007 08125: filed on July 17, 2007 ; published on December 10, 2007. Bul. No. 20. 6 pp. (in Ukrainian).

16. Small-arms silencer: Patent 36674 Ukraine: IPC (2006) F41A 21/30 (2008.01), F41A 17/00. Konovalov M. A., Pylypenko O. V., Polyakov G. A., Pugach Ye. O., Skorik O. D., Kovalenko V. I., Strelnikov G. O., Chaplyts O. D.; applicant and patentee Institute of Technical Mechanics of 
the National Academy of Sciences of Ukraine and the National Space Agency of Ukraine. No. u2008 01456: filed on February 4, 2008 ; published on November 10, 2008. Bul. No. 21. 6 pp. (in Ukrainian).

17. Firearm silencer: Patent 84118 Ukraine: IPC (2006) F41A 21/30 (2008.01), F41A 17/00. Konovalov M. A., Pylypenko O. V., Skorik O. D., Pugach Ye. O., Pugach O. M. ; applicant and patentee IMKAS Ltd. No. a2008 05748: filed on May 5, 2008 ; published on September 10, 2008. Bul. No. 17. 4 pp. (in Ukrainian).

18. Small-arms silencer: Patent 89310 Ukraine: IPC (2009) F41A 21/30 (2008.01), F41A 17/00. Konovalov M. A., Pylypenko O. V., Polyakov G. A., Skorik O. D., Strelnikov G. O., Chaplyts O. D.; applicant and patentee Institute of Technical Mechanics of the National Academy of Sciences of Ukraine and the National Space Agency of Ukraine. No. a2008 08435: filed on June 24, 2008 ; published on January 11, 2010. Bul. No. 1.6 pp. (in Ukrainian).

19. Small-arms silencer: Patent 44753 Ukraine: IPC (2009) F41A 21/30 (2009.01), F41A 17/00. Konovalov M. A., Pylypenko O. V., Polyakov G. A., Pugach Ye. O., Skorik O. D., Strelnikov G. O., Chaplyts O. D.; applicant and patentee Institute of Technical Mechanics of the National Academy of Sciences of Ukraine and the National Space Agency of Ukraine. No. u2009 05084: filed on May 22, 2009 ; published on October 12, 2009. Bul. No. 19. 4 pp. (in Ukrainian).

20. Small-arms silencer: Patent 94790 Ukraine: IPC (2011.01), F41A 21/30 (2006.01), F41A 17/00. Konovalov M. A., Pylypenko O. V., Polyakov G. A., Avdieiev A. M., Pugach Ye. O., Skorik O. D.; applicant and patentee Institute of Technical Mechanics of the National Academy of Sciences of Ukraine and the National Space Agency of Ukraine. No. a200908628: filed on August 17, 2009 ; published on June 6, 2011. Bul. No. 11. 6p p. (in Ukrainian).

21. Small-arms silencer: Patent 94491 Ukraine: IPC (2011.01) F41A 21/30 (2006.01), F41A 17/00. Konovalov M. A., Pylypenko O. V., Avdieiev A. M., Pugach Ye. O., Skorik O. D.; applicant and patentee Institute of Technical Mechanics of the National Academy of Sciences of Ukraine and the National Space Agency of Ukraine. No. a200907528: filed on July 17, 2009 ; published on May 10, 2011. Bul. No. 9.5 pp. (in Ukrainian). 